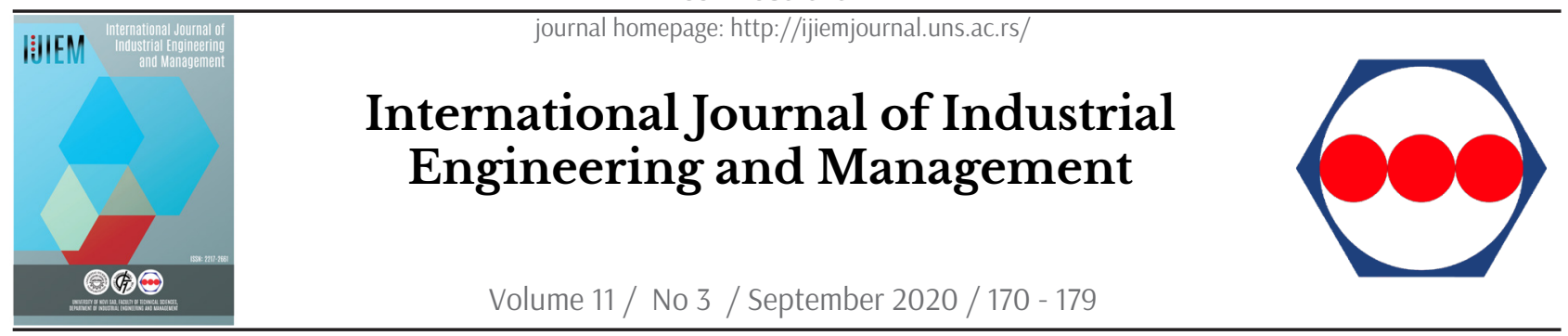

Original research article

\title{
Social management for people later age in service sector: status and prospects
}

\author{
N. Bukhalova, O. Pavlova * \\ Nizhny Novgorod State Engineering and Economic University, the Department of Humanities, Knyaginino, Russia
}

\begin{abstract}
A B STRACT
The purpose of this paper is to identify the features of the formation and functioning of the social services market for the elderly. Using the example of Nizhny Novgorod region and statistical data analysis, the assessment of the sphere of social services for late-age citizens was given, the problems of social assistance system functioning were identified, solutions were proposed. Results showed that the inconsistency of actions of social assistance structures at different levels, the separation of support measures, the lack of special status for family and relatives require to streamline the interaction of existing market participants and promote the emergence of new ones.
\end{abstract}

\section{ARTICLE INFO}

Article history:

Received July 3, 2020

Revised September 7, 2020

Accepted September 10, 2020

Published online September 22, 2020

Keywords:

Social management;

Social service;

Elderly people

*Corresponding author:

Olga Pavlova

olgapavlova08@yandex.ru

\section{Introduction}

The global trend of increasing life expectancy and increasing the number of elderly people is also characteristic of modern Russia. The older age cohort increases faster than other age groups. The World Health Organization (WHO) predicts that between 2015 and 2050, the world's population aged 60 and over will more than double from 900 million to 2 billion, that is, from $12 \%$ to $22 \%$ of the total world population. By $205080 \%$ of all elderly people will live in middle- or low-income countries [1]. Population aging has regional specifics, so the increase in the share of elderly people in the demographic structure of European countries began more than a century ago, while in the Eastern and South American regions this trend has been observed only in recent decades. For example, in France the increase in number of older age cohort from $10 \%$ to $20 \%$ of the total population of the country continued during 150 years; similar indicators will be achieved only in two or three decades in such countries as Brazil, India and China [2]. Thus, world population aging will occur in the coming decades. These paces of change in the age structure of population require serious rethinking and transformation of social system of society in general.

Research problem and tasks are the necessity of changing the structure and principles of providing of social services for elderly in relation to global popula- 
tion aging process.

Research tasks are

- analysis of scientific literature on population aging;

- analysis of statistics on demographic processes in relation to elderly persons;

- analysis of international and Russian practice of providing social services to people of the older age cohort;

- identification of problems in traditional system of social services for the elderly by conducting a sociological research (interview) of social service workers.

The author's position is that the market for social services for elderly in Russia does not meet the needs of customers and requires modernization. In order to analyze the social services market, the authors distinguish two groups of variables: 1) objective indicators - demography, differentiation within the older age cohort, social services system; 2) subjective indicators (subjects of social services market) - client's needs, capabilities of social services provider.

After reaching the border of old age, modern person lives an average another 20-25 years. Nowadays the group of elderly people is extremely heterogeneous, because biological aging has only conventional age limits. There are many classifications of elderly in modern science. For example, the WHO classification: elderly person is $60-75$; senile period - 75-90; 90+ is long-liver. A. Burnside distinguishes four periods: 60-69 is presenile; 70-79 - senile; 80-89 - late senile; 90+ is decrepitude (senility) [3]. Russian researcher I.S. Kon identifies 4 types of old age, focusing on the nature of human activity. The first type is "active" old age, the second is "creative" old age, the third is "family" old age and the fourth is "healthy" old age [4]. Focusing on the realities of modern Russian society, in this article the marker of old age is the retirement age (60 years for women and 65 years for men).

\section{State of the art}

The problems of population aging and social support for elderly have been the subject of scientific discourse in Russia since the end of the XX - beginning of the XXI century [5, 6, 7, 8]. A number of problems related to the aging of the population were predicted at the turn of the century. In particular E.I. Kholostova identifies four groups of problems: demographic and macroeconomic; transformation of social networking; changing in the structure of labor market; social and health services for elderly [9]. In Russia these problems have become even more acute due to radical social, political and economic changes in the period of Perestroika in 90-ies of the XX century [10, 11,12].

To ensure a healthy, full and prosperous life for people of the older age cohort, a scientific understanding of the problems and trends of aging is required. One of the main tasks of an aging society is to preserve the social activity of elderly, their relevance in the family and society. The transformation of demographic structure of society requires the modernization of number of institutions of society and their subsystems, in particular health and social support, culture and sports, education and family. Issues related to the development of social services market for elderly are becoming relevant. The analysis of papers of foreign and domestic researchers has shown that the problem of formation and development of social service system (focused on clients of an older age group) is being solved today in most countries of the world [13, 14, 15]. The most relevant issues are demand and effectiveness of different types of social support for elderly [16], as well as their qualitative assessment, economic component and determination of profitability of a particular social service [17, Pp. 147-148].

One of the main trends in the field of social services has been the formation of the private sector in the social services market. The emergence of private providers in the field of social and medical services for the elderly not only enriched and expanded the state support system, but also provoked a number of problems, one of which is the possibility of state control over their activities. For this purpose, the constituent entities of the Russian Federation form a register of social service providers. Other countries also have experience in improving public management services for business registration [18].

The private sector in the provision of social services has grown much earlier in Europe and Asia. Hence, in Sweden, the transformation of system of social services for the elderly began in the 90 s of the $\mathrm{XX}$ century, where the share of paid social services provided to people of later age increased from $1 \%$ to $16 \%$ [19]. Research of quality of paid and state social services showed their significant difference. Comparison of such assessment criteria as service structure, staff burden, volume and duration of service delivery, showed that state and private social service providers prioritize differently. In the state sphere, the focus is on the structure of services for the elderly; paid 
social services are more personalized and variable. The transformation of the social services market was also influenced by digitalization, as a result of which Internet services for elderly appeared and are actively used in countries with developed online infrastructure. The practice of spreading new technologies and online services in Japan and Great Britain has shown the willingness of significant part of elderly to use online services [20]. The degree of loyalty to innovations in the field of social services depends not only on the digital literacy of older people, but also on social activity, the breadth of social connections, and self-perception.

Similar trends are observed in Russia (see Fig. 1). The total number of pensioners according to Rosstat over the past seven years has grown by more than 4 million people.

For every thousands of employed populations at the age of 15 years and older, there are 510 elderly people in Russia today.

The situation with elderly people in Nizhny Novgorod region reflects the all-Russian one. The number of pensioners in region over the past year has increased by $0.4 \%$, or by 3,900 people. In branches According to the pension fund of the Russian Federation in Nizhny Novgorod region, the number of pensioners on January 1, 2019 was 1,054,100 people. For every thousands of working age population over 15 years old, there are 574 old-age pensioners. Based on the total population on January 1, 2019, the share of pensioners was 32.8 percent, so almost every third resident of Nizhny Novgorod region is a pensioner [12].

The legal base for supporting older people began to take shape several decades ago and continues to be actively improved today. The main legislative acts regulating the situation of elderly citizens are the Constitution of the Russian Federation, Federal Law №178 "State Social Care Support Act” [22], and Federal Law №181 "About Social Protection of Persons with Disabilities in the Russian Federation" [23]. In February 2016, government decree №164-r adopted the strategy of actions in the interests of older citizens in the Russian Federation until 2025 [24].The strategy focuses on the necessity to develop a state policy "concerning taking care of older citizens, their families, social institutions that interact with this category of citizens, but also in active involvement of older citizens in society," which will result in the formation of a tolerant society; eliminating stereotypes of ageism; coordination of fundamental social institutions activities, such as state, economy, education, family. Under federal law, the main tool for implementing state social policy is the social service system. According to the National Standard of the Russian Federation, social services for the population, social services for senior citizens "are aimed at ensuring economic stability and social security of citizens, consisting in the implementation of necessary preventive measures to protect them from undesirable life factors, defined as a difficult life situation and characterized by possible poverty, illness, homelessness, loneliness, criminal danger and other negative factors. The provision of the services specified in this standard ensures the social security of citizens in all its aspects (domestic, medical, psychological, legal) throughout the entire stay of citizens in the institution, and also contributes to their socialization and further integration into society after withdrawal from social services"[25].It can be seen from the presented document that the Russian market of social services for the elderly is aimed at providing assistance in difficult life situations and

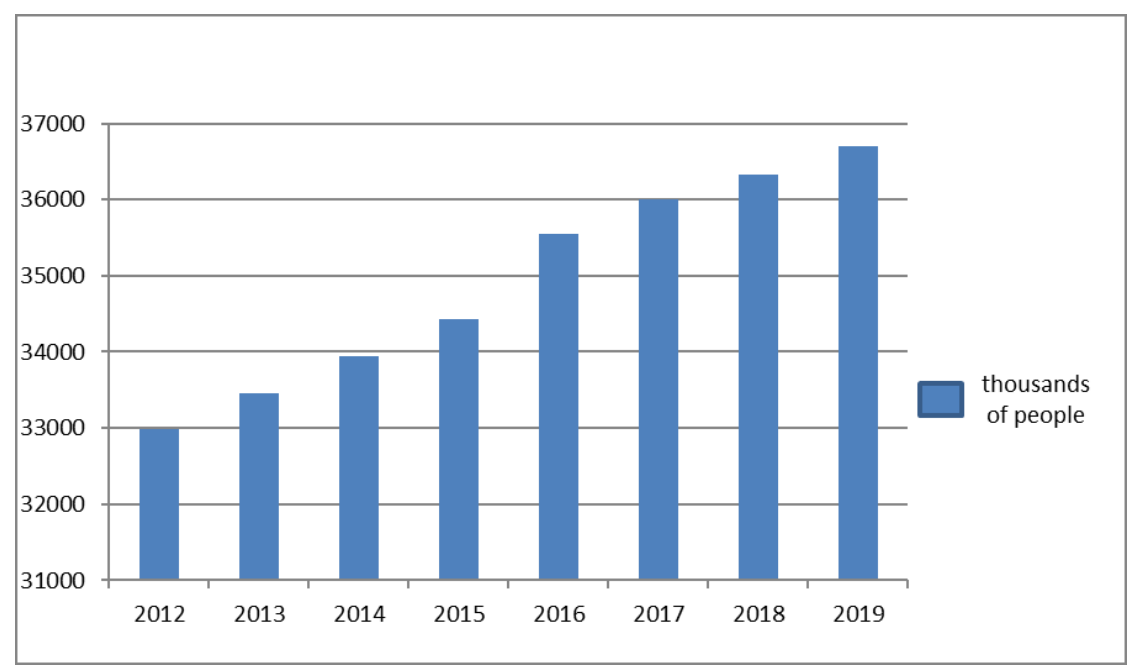

Figure 1. Diagram of number of old-age pensioners in Russia [21] 
palliative care; representatives of the older age cohort are perceived as passive recipients of services.

Among the providers of social services oriented to an older age cohort, we can distinguish gerontological centers, centers providing psychological and pedagogical assistance, comprehensive service centers for citizens, specialized homes for the elderly, and centers for social and medical care with stationary and semi-stationary accommodation. The existence of emergency assistance and support services in crisis situations is undeniable, but there is an objective need to transform the social support system in accordance with the needs of the elderly and provide them with comprehensive assistance. Focusing on the features of social services for elderly people, it should be noted that these features are determined by physiological and social and psychological changes that occur at old age. Romanichev I.S. [26] indicates that age-related changes "cause the correction of status-role relations, exacerbate some needs and blunt others, cause differentiation of the elderly population in terms of the level and form of social adaptation to old age. The system of social services for senior citizens provides for the provision of services of various forms and contents depending on certain characteristics of the client - the ability to self-service, maintain of intellectual potential, general state of health, level of creative development, availability of regular and self-replicating social contacts” [26].

The position of an elderly person in society is largely determined by his social activity. According to the results of international population researches for 2014, the index of life quality and well-being of elderly Russians was in 65th place [27].

According to the Federal Law, Social Service is defined as "an action or actions in the field of social services for the provision of constant, periodic, onetime assistance, including emergency assistance, to citizen in order to improve his living conditions and (or) expand his ability to independently provide for his basic life needs [28]. Services for elderly are provided in stationary, semi-stationary form and in the form of social services at home or in specialized in- stitutions of social services. In this article, we include the concepts of "Social Support" and "Social and Medical Assistance" in the concept of "Social Services". Realities of time require the modernization of social service system for elderly people, especially reorientation from providing assistance in difficult life situations and palliative care to services that contribute to maintaining social activity of people of an older age cohort and activating their personal potential.

The analysis of social services of older persons can be based on various criteria, for example, the legal base, the structure of social services, the age of the elderly client and his or her well-being, needs and ways of satisfying them. The indicated analysis perspectives are clearly reflected in the register of social service providers. Nowadays it is one of the objective sources reflecting the specifics of the market of the social security system of the constituent entities of the Russian Federation. According to the Register of Social Service Providers of Nizhny Novgorod Region [29], there are 126 organizations providing social services to representatives of the older age cohort.

It should be noted that the registration of organizations providing social services in the register is not obligated, this is a voluntary procedure. The real picture of social service providers may also include organizations that are not registered in the registry. Organizations specializing in providing services to elderly people account for $58 \%$ (i.e., every second organization) of the total number of social assistance organizations. Multifunctional centers of social services, including services for the elderly, are available in almost every district of the region.

The number of old-age pensioners in the city is 373.666 people according to the Department of Social Policy of Nizhny Novgorod [30]. The oldest age cohort of the region is 680.434 people. The number of organizations providing social services is distributed as follows: 21 are in regional center, 105 - in region. The number of organizations and institutions of social support for older people is sufficient. Of the total number of organizations providing social services to the elderly, $55.5 \%$ are specialized institutions.

Table 1. Organizations providing social services to the elderly [21]

Specialized institutions for the elderly

Multifunctional social services centers including services for the elderly

\begin{tabular}{lll}
\hline NizhnyNovgorod & 4 & 17 \\
Districts of Nizhny Novgorod Region & 66 & 39 \\
Total & 70 & 56 \\
\hline
\end{tabular}


Specialized organizations for the elderly provide both stationary and semi-stationary services.

Russian market for social services for people of later age includes the state, public and private segments. The state sector prevails, being a monopolist and dictating terms to consumers of services. Private suppliers are more focused on another segment of the market due to the low paying capacity of the elderly, the specifics of working with this category of citizens, and the insufficient level of professional competencies.

Despite the problems, the private sector in the social services market is available and developing, albeit not in sufficient quantities. One of the problems of weakness of social entrepreneurship is the lack of institution for coordinating the actions of social services market participants. For example, M.E. Elyutina [31] focuses on this issue, pointing out the imperfection of the legal base, duplication of work, lack of single information environment. According to the author's opinion, "there is no mechanism for implementing intersectoral interaction nowadays. An important question is the legitimation of relationship of non-governmental network of social support for the elderly with professional state system” [31].

Another problem of private market in social sector is the risks of investing in social sphere. Psychological and physiological peculiarities of older persons, as well as lack of an informative base on all subjects of the social services market, material resources create difficulties in making positive decisions of investing in the sphere of social services [32].

The range of social services for senior citizens is diverse: social and household, social and medical, social and psychological, social and pedagogical, social and labor, social and legal, services in order to increase the communicative potential of recipients of social services with disabilities. Analyzing the components of types of social services, it should be noted that the vast majority of them are not aimed at preserving a person's social activity at later age, but maintaining a satisfactory physical condition and surviving. "Active" types of services (aimed at maintaining of social status) include social and pedagogical (training in self-service skills, behavior in everyday life and public places, self-control, communication skills and other forms of public life), social and labor (assistance in finding employment) and services aimed at improving the communicative potential of person (training in the use of technical means of rehabilitation, assistance in teaching computer literacy skills). Other types of services, such as social and household, social and medical, social and psychological, social and le- gal are "passive" ones.

At early stage of aging, most elderly continue to lead an active lifestyle, focused on continuing to work and maintaining social communication. This is confirmed by Russian researchers [33, 34]. At this stage of life, the services of social assistance organizations are less demanded. "Young" elderly are interested in receiving services for organizing active leisure, cultur$\mathrm{al}$ and sporting events, spa treatment, and the realization of creative abilities. At later stages of aging, there is an increasing need for organizing of everyday life, psychological and medical care. In this regard, it is necessary to gradate the types of social services for a particular ageing period.

\section{Materials and methods}

Analysis, synthesis methods, statistics method, mathematical methods are used. This paper contains a theoretical analysis of the concepts of "Social Management", "Social Service" and "Elderly". The statistics data characterizing demographic processes were analyzed. Data about producers of social services were presented on the example of register of social service providers in Nizhny Novgorod region. The article presents the results of author's sociological research of social service workers conducted in Nizhny Novgorod region. Qualitative sociological methods were used to analyze the features of interaction between suppliers and consumers of social services market. In 2019 a sociological survey of practitioners in the sphere of social services to elderly citizens was conducted $(n=40)$. The geography of research is Nizhny Novgorod region; the research method is a standardized interview that involves conversation based on a rigidly fixed questionnaire. The interview is based on the methodology of Russian sociologists V.A. Yadov, I.A. Butenko, O.A. Voronkova and Yu.P. Voronkov. The main quotas for selecting respondents were work experience in the field of social services for the elderly for at least five years, settlement status (city, village), type of customer service (home service). The search for respondents was carried out using the snowball method.

\section{Results}

In 2019 a sociological survey of workers in provision of social services to senior citizens was conducted $(n=40)$. The qualitative research is devoted to study of the second subjective variable identified by authors (work features of social service providers). 
Research geography is Nizhny Novgorod region, research method is standardized interview. Work experience of an expert in the field of social services for the elderly, type of customer service, settlement status was quotas for respondent's selection.

The purpose of interview is to study the features of the work of social service providers for the elderly.

Tasks are

1) to identify the features of communication with elderly client in the process of social services providing;

2) to identify the problems of traditional social support system for elderly.

The results of this survey allowed us to make following conclusions:

1) process of communication with elderly client is determined by two main factors during the provision of social services: psychophysiological features of elderly and territorial settlement status.

Social workers emphasize the special status of an elderly person, necessity of increased attention not only to physical well-being of older clients, but to psychological state. Emotional instability, mood swings, and tendency to depression are noted. "It's easy to communicate with someone, but you don't want to talk with others. You must take into account their age, their perception of environment. Some have lived their whole lives in a positive way and haven't lost their sense of humor; while others, due to their illnesses and feelings of uselessness, have become embittered all over the world. Someone gave up on themselves and constantly repeats: "I wish I die soon". We need to find our own approach to everyone"(female of 52 years old, work experience is 14 years). Health problems, chronic diseases, movement difficulties affect the nature of communication. "They need more compassion, moral support, sympathy" (female of 45 years, work experience is 13 years). The age difference between social worker and older client is a common cause of problems in providing social assistance. Representatives of an older age cohort are conservative in their views and habits, and are not always able to objectively take expert advice. “...different life views, you have to adjust, because when you try to prove yourself, you run into a wall of misunderstanding of each other. We ... try to hear each other" (fe male of 37 years old, work experience is 9 years).
The place of residence of older clients also effects on specifics of the provision of social services. Interaction in rural areas is often based on personal acquaintance and is not limited by official list of provided services. According to social service specialists, older villagers are more open in communication, loyal to social worker, and more easily compromise. Developed urban infrastructure and, as a result, the possibility of choice increase the demand of customers both to social worker and to the service content. "Urban elderly often require the delivery of goods from certain outlets (one friend said that it is better), and it does not matter that these points are located in different parts of the city. Urban elderly are more demanding about visiting times, and are more likely to get annoyed if social worker is delayed. And the reason is not important here" (female of 37 years old, work experience is 11 years).We need a social management system that would contribute to the development of professional competencies of workers in social sphere, could clearly coordinate the provision of social assistance to elderly at all levels of social system.

2) traditional social support system for elderly does not meet to modern needs of older client and requires modernization. Customization of social services for citizens of an older age cohort should be one of aspect of modernization.

The most urgent problem of working with representatives of older generation (according to social workers) is the low quality of technical equipment, the lack of necessary equipment, which forces to seek help outside. The situation is exacerbated by the lack of specialized organizations in rural areas. "In our village there are very few men who are engaged in side job, and those who could help are working people. ... I use family help, my husband helps me" (female of 37 years old, work experience is 9 years). Lack of medical knowledge also negatively affects the process of providing social services to older people: “... sudden health problems, sometimes I'm afraid that I won't be able to help in a difficult situation..." (female of 52 years, work experience is 14 years), “... I often had a lack of medical knowledge, but over the years you know the patients' illnesses by heart. I have a doctor's assistant in my neighborhood, we get along well, and she can help me at any time" (female of 47 years old, work experience is 12 years). Another serious problem is emotional burnout 
“...you feel moral emotional fatigue, because I have to pass all their problems and emotions through yourself" (female of 37 years old, work experience is 11 years). This problem was discussed by specialists who have worked in the field of social services more than ten years.

Difficulties of interpersonal communication (mentioned above) are solved individually with each elderly client. However, there are a number of problems that need to be addressed to regional and federal levels. During the interview respondents pointed out that actions of social assistance structures are inconsistent at different levels, support measures are separate, and families and relatives who care for the elderly do not have a special status. Existing employees spoke about the feasibility of developing of coordinating component in modern social services market. In their opinion, it is necessary to streamline the interaction of existing market entities and initiate the emergence of new ones. This function will be performed by social management. Social management can contribute to family integration into system of social care for elderly as a full subject of social service.

\section{Discussion}

As practice shows, the modern system of social work does not always have time to adapt to the pace of social change. Social needs are more mobile than their satisfying system. These processes are also typical for gerontology. "Social work with older clients (state) is based on the traditional paradigm; it is characterized by less flexibility compared to the provision of social services to other (more resourceful) clients. Non-governmental social work is developing unevenly, different types of scientific and commercial associations present ordinary forms of care along with innovative ones" [35].

From the analysis presented above, it is clear that the range of social services is quite diverse, but does not take into account the age characteristics of older people, professional, educational status, settlement specifics, ethnic and confessional characteristics, and cultural aspect. Social service providers (government agencies, noncommercial organizations, and social entrepreneurship) are not always customer-oriented, which affects the quality of service. Subject and object relations in social services market are disparate, not all the capabilities of some are used and all needs of others are not satisfied. Therefore, social services need to be customized, when the content of the service is determined jointly by its supplier and consum- er, adapting the service to the needs of a particular person.

Thus, nowadays two contradictory processes are clearly visible in the social services market in Russia: simplification and customization. Simplification of social services involves standardizing and reducing the volume of services to an economically reasonable minimum, which is typical for the public sector. Customization of social services provides the individualization of services to the needs of a particular consumer, and private providers of the social services market have wide opportunities to implement this process. Ideally, these two processes should balance each other, creating optimal conditions for meeting the needs of older clients in social services market.

Social management is called upon to solve the issue of the effective provision of social services to older people. Social management is a young management industry. Its task is to ensure effective management in the system of social relations in general, and in its individual areas. Thinking widely, social management is a social institution consisting of a rationally constructed system of institutions and naturally developing relations of participants in social interactions [36]. Thinking narrow, it is interpreted as a special type of professional activity. In this paper, social management is considered as a type of professional activity.

In the context of transformation of Russian social services market, characterized by an increase in the number of suppliers and consumers of social services, the emergence of new technologies for working with clients, innovative processes, there is an objective need to coordinate work in the social sphere, in particular in working with older people. The authors' position is confirmed in papers of other researchers of social management problems [37].The priority areas of social management in gerontology are creation of conditions for healthy competition in the provision of social services, development of innovative forms of social services, management of financial flows, creation of alternative types of work and, as a result, expansion the choice of service types, i.e. in general, the regulation of supply and demand in social services market.

Among the innovative forms of social services practiced both in the world and in Russia, hospital-replacing technologies for working with older people are becoming increasingly important ("nurse at home”, informal long-term care, substitute family, "model apartment for family with a demented patient").

Hospital-replacing technologies are aimed at 
maintaining of high social status and social connections of an elderly person. Family plays a key role in implementation of these technologies. The European practice of placing later-aging people in specialized nursing homes is also being implemented in Russia, but it is not widespread. Traditionally, the older generation maintains close contact with children and close relatives, what is typical for a society with a predominance of extended family type. A small nuclear family is a norm for modern Russia [38]. The circle of kinship is reduced, which increases the likelihood of lonely old age. An alternative to family with children or relatives becomes a substitute family [39].

The traditional system of social assistance for the elderly does not consider the family as an active participant in the social services market. Not being the subject of legal relations, family with an elderly relative (who requires care) is forced to independently cope with problems; the most relevant of which are material, lack of care skills and lack of technical means. In this case, social management could act as a tool to solve the above problems and make family a full member of social service sector. Family for an elderly person is not only the basis of social stability, but also provides sustainable interaction with health organizations and social services. Thanks to it, elderly citizens remain active participants in social relations for a long time.

The scheme "The role of social management in the field of social services for the elderly" is presented in Figure 2.

Thus, the role of social management in the field of assistance and support for elderly people (the purpose of which is to develop effective strategies of interaction subjects at social services market) is to coordinate the actions of all components of this process.

One of the most important principles of providing services to elderly people should be targeted nature. Thanks to this principle, first of all, psychological problems of transition to a new stage of life are eliminated and an active social position is maintained, autonomous living in usual conditions is prolonged, and the quality of life generally improves. Social management allows to evaluate the effectiveness of provision of social services to people of an older age cohort. The principles of effectiveness of social services provision are volume, complexity and duration, the degree of their adequacy to social demand and needs of elderly. We need a social management system that would contribute to the development of professional competencies of social workers and would clearly coordinate the provision of social assistance to elderly at all levels of social system.

Social management plays an important role not only in organizing the provision of high-quality social services to senior citizens, but also contributes to continuous improvement of professional competence of specialists in social assistance and support services. Traditional forms of professional competence development are training at specialization in "social work" and "social service" in educational institutions, certification and obtaining an appropriate category, training in advanced education courses and retraining, participation of social service specialists in trainings,

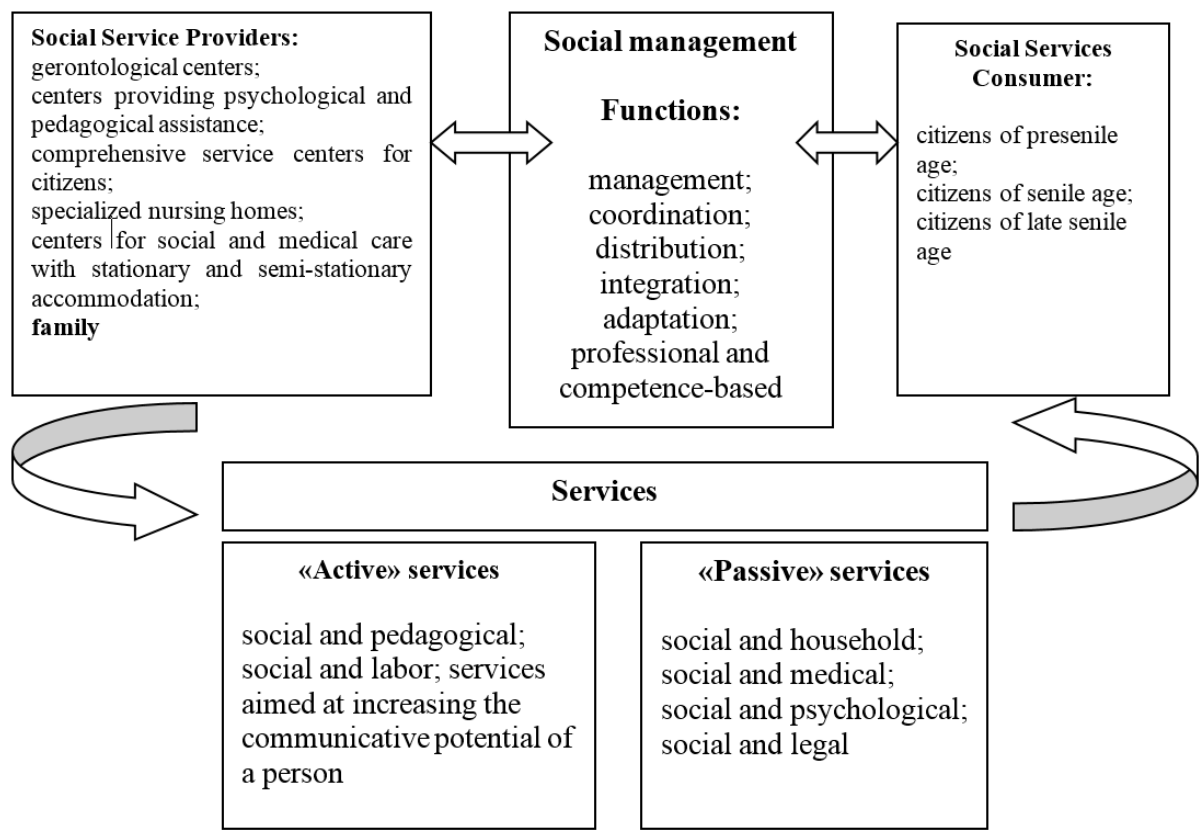

Figure 2. The scheme "The role of social management in the field of social services for the elderly" 
seminars and various kinds of events for experience exchange, as well as self-education classes. All these ways to improve professional competencies will have a positive impact on effectiveness of service delivery.

\section{Conclusion}

The global demographic problem of population aging requires the transformation of traditional system of social assistance and support for people of later age.

Analysis of objective and subjective variables showed:

1. The ageing of population in Russian is typical and corresponds to global trends, which allows using foreign experience in the field of providing social services to older citizens.

2. The increase of longevity provoked the differentiation of the cohort of older people according to such criteria as psychophysiological, adaptation aspects, employment, family, cultural and educational statuses, which led to a variety of needs in social services market.

3. Traditional support system of elderly population in modern conditions has proved to be untenable and needs to be modernized through introduction of innovative forms of work, emergence of new subjects of social service, and expansion of social services range.

4. At the macro level social management can fulfill the role of coordinator in the field of assistance and support. It can be done by developing effective strategies for interaction between participants of social services market and coordinating the actions of all components of this process.

5. It is necessary to take into account regional specifics when designing a model of social management in the field of support and service for elderly: size of federal subject, population, regional economic development, national and confessional traditions. These factors will have an impact on the process of customization of social services for elderly citizens.

6. At the level of individual interaction, family can become a new effective subject in social services market, with the status of full participant in the process of creating and providing services to older citizens.

\section{Funding}

This research did not receive any specific grant from funding agencies in the public, commercial, or not-for-profit sectors.

\section{References}

[1] What are the implications of an aging global population for public health? Official website of the World Health Organization [Electronic resource]. Access mode: https://www.who.int/topics/ageing (accessed 18.02.2020).

[2] 10 facts about aging and health [Electronic resource]. Access mode: https://www.who.int/features/factfiles/ageing/ru/ (accessed 28.05.2020).

[3] Burnside, I. M. (1979). The later decades of life: Research and reflections. In I. M. Burnside, P. Ebersole, \& H. E. Monea (Eds.), Psychosocial caring throughout the life span. NewYork: McGraw-Hill.

[4] Kon I. S. In search of yourself: personality and selfconsciousness. - M: Politizdat, 1984. - 335 p.

[5] Kozlova T.Z. Social time of pensioners: stages of selfrealization of personality. M. 2003, 228 p.

[6] Social policy and social work in changing Russia / Under edition of E. R. Yarskay - Smirnova, P. E. Romanov. Moscow. INION RAN. 2002. 456 p.

[7] Shchukina N.P. Institute of mutual assistance in system of social support for elderly. Moscow: Dashkov and K. 2004, 412 p.

[8] Eftimovich L. About targeted support for pensioners // Social security 2003. №9. Pp. 8-11.

[9] Kholostova E.I. Social work with elderly: educational and methodological book - Moscow: Publishing and Trading Corporation "Dashkov and K", 2003. 296 p.

[10] Shkinder N. L. The importance of social standards in institutionalization of social services for older people in modern Russia // Social policy and sociology. 2010. №12(66). Pp. 95-103.

[11] Grigorieva I. Social policy in Russia: search of options and directions for transformation // Social policy in modern Russia: reforms and everyday life. Moscow, 2008. Pp. 19-24

[12] Yarskaya-Smirnova E. R., Romanov P. V. New ideology and practice of social services: assessment of effectiveness in the context of social policy liberalization // Journal of Social Policy Research. 2005. T3. №4. Pp. 497-523

[13] Marco Angrisani, Jinkook Lee Cross-country analysis of retirement, Health, and wellbeing editorial The Journal of the Economics of Ageing. May 11, 2020 [Electronic resource]. Access mode: https: //doi.org/10.1016/j.jeoa.2020.100263 (accessed 04.06.2020)

[14] Carl N. Mason, Timothy Miller, (2018) International projections of age specific healthcare consumption: 2015-2060. The Journal of the Economics of Ageing. Volume 12. Pp. 202-217.

[15] Perelman G. I. Foreign experience of social and pedagogical work with elderly // Development of professional competence of specialists in the field of rehabilitation and education of disabled people. Materials of scientific and practical conference. - St. Petersburg: Publishing House St. Petersburg SRP "Pavel”. 2012. Pp. 79-80.

[16] Marko M. Mihic, MarijaLj. Todorovic, Vladimir Lj. Obradovic (2014) Economic analysis of social services for the elderly in Serbia: Two sides of the same coin. Evaluation and Program Planning, Volume 45. Pp 9-21.

[17] The Cost-Effectiveness of Continuous Versus Intermittent Renal Replacement Therapies in Acute Kidney Injury: 
Perspective of the Social Services for the Elderly in Argentina Value in Health Regional Issues. Volume 20. (2019) Pp. 142-148.

[18] R. Andersson, E. Bridi, Y.P. Baez, M.U. Maldonadom, F.A. Forcellini, and F.C. Moraes, "Improvement in Public Administration Services: Case of Business Registration Process,” Int. J. Ind. Eng. Manag., vol. 9, no. 2, pp. 109-120, 2018.

[19] RagnarStolt, Paula Blomqvist, UlrikaWinblad (2011) Privatization of social services: Quality differences in Swedish elderly care Social Science \& Medicine. Volume 72, Issue 4. Pp. 560-567.

[20] KunioShirahada, Bach Quang Ho, Alan Wilson (2019) Online public services usage and the elderly: Assessing determinants of technology readiness in Japan and the UK Technology in Society. Volume 58. Pp. 101-115.

[21] Pension support in Nizhny Novgorod region [Electronic resource]. Access mode: https: // nizhstat.gks.ru (accessed 04.06.2020)

[22] Federal Law №178 "About State Social Assistance" [Electronic resource]. Access mode: http://www.consultant. ru/document/cons_doc_LAW_23735/ (accessed 04.06. 2020)

[23] Federal Law №181 "About Social Protection of Persons with Disabilities in the Russian Federation" [Electronic resource]. Access mode: http://www.consultant.ru/ document/cons_doc_LAW_8559/(accessed 04.06.2020)

[24] Order №164-r About the approval of the Strategy for Action in the Interests of Senior Citizens in the Russian Federation until 2025 [Electronic resource]. Access mode: http://docs. cntd.ru/document/420334631 (accessed 04.06.2020)

[25] National standard of the Russian Federation Social services of the population. Social services given for elderly citizens [Electronic resource]. Access mode: // http://docs. cntd.ru/document/1200107240 (accessed 04.06.2020)

[26] Romanychev I.S. Social service for elderly people through the prism of utilitarian classification of needs // Domestic Journal of Social Work. 2010. №4. Pp. 69-80.

[27] Solnyshkina M.G., Tyukin O.A. Social risks of elderly Russians who do not receive social services at home // Knowledge. Understanding. Skill. 2015. №2. [Electronic resource]. Access mode: https://cyberleninka.ru/article/n/ sotsialnye-riski-pozhilyh-rossiyan-ne-poluchayuschihsotsialnye-uslugi-na-domu. (accessed 16.02.2020)

[28] Federal Law №442-FL "About the Basics of Social Services in the Russian Federation" [Electronic resource]. Access mode: https:/mszn27.ru/sites/files/mszn/kgu/ tkcson/files/af4337d31935af39fd54.docx

[29] Register of social service providers in Nizhny Novgorod region [Electronic resource]. Access mode: https:// minsocium.ru/index.php/sotsialnoe-obsluzhivanie/reestr

[30] Social passport of Nizhny Novgorod. [Electronic resource]. Access mode: https: //нижнийновгород.РФ (accessed 04.06.2020)

[31] Elyutina M.E. Institutional forms of care for the elderly // Practices of care in modern society Materials of All-Russian scientific and practical conference. 2017. Pp. 88-94.

[32] Zolotareva T.F. Non-stationary social service and quality of life of elderly // Domestic Journal of Social Work. 2010. №4. Pp. 88-93.

[33] Burtseva I.V. Healthy lifestyle of elderly as a factor of social longevity // The value system of modern society. 2012. №22. Pp. 281-285.

[34] Saralieva Z.Kh., Petrova I. E. Elderly in Russian nongovernmental social work // Journal of Social Policy Studies, Volume 16. №1. Pp. 95-108.

[35] Shipunova T. V. Evolution and problems of social work management // Management Consulting. 2009. №2. [Electronic resource]. Access mode: https:// cyberleninka.ru/article/n/evolyutsiya-i-problemy-menedzh menta-sotsialnoy-raboty (accessed 16.02.2020)

[36] Moskvitina N. M. Features of management in social work // Bulletin of Amur State University. Series: Natural and Economic Sciences. 2013. №61. Pp. 121-124.

[37] Khalikova G. R. Management in social work // Young scientist. 2014. №20(79). Pp. 541-543.

[38] Egorova N.Yu. Contemporary family in a system of matrimony-parenting-kinship // Family human ecosystem: monograph / Z.Kh. Saralieva, G.L. Voronin, S.A. Sudin, D.A. Shpilev and others. - N. Novgorod: Publishing house LLC Research sociological center, 2018. -Pp. 34-53.

[39] Sidorchuk T.A. Foster family for an elderly person in Smolensk region // Creative heritage of E.V. Ilyenkovand present day. 2017. №3. Pp. 94-101. 